\title{
A NEW VIEW ON SOCIAL ADAPTATION OF THE MILITARY, DISCHARGED FROM MILITARY SERVICE IN BULGARIA
}

\author{
Venelin Terziev \\ Professor, Ph.D., D.Sc. (National Security), D.Sc. (Ec.), University of Rousse, Rousse, Bulgaria, \\ National Military University, Veliko Tarnovo, Bulgaria, terziev@skmat.com
}

\begin{abstract}
The thesis resulting from the research on the "costs-effects" relation is the principle of economic efficiency of defence capabilities. At first glance, the arguments in this direction are well-known and popular in crisis situations of various nature, including the current financial and economic crisis in the country, the question about the cost of public welfare- security and defence is debatable. This cost is manifested through the defence capabilities of a country. In the new security environment the compilation of a National Defence Strategy is a priority of the Defence Ministry, which has more and more limited resources. This means that they should be treated as an economic activity. An economic activity is considered "any purposeful activity, allocating and combining scarce resources among alternatives, making it possible to maximize the outcomes and minimize costs". The ratio between the costs and benefits of a given resource or combination of resources to achieve a pre -defined objective is pushed to the forefront and the rationalization of management decisions is based on it. This necessitates a cost effectiveness analysis hence the evaluation of the outcomes (benefits) is manifested in the "cost-effect (benefit)" analyses.
\end{abstract}

Keywords: Social work, social management, social adaptation of military.

\section{INTRODUCTION}

Social work is a relatively young, gaining distinction nowadays as a rapidly growing branch of knowledge and practical work, whose development has not been completed yet. Having emerged as a social phenomenon and a special area of human activity, it has been on a more frequent basis attracting the attention of those engaged in the field of research and becoming subject of special scientific studies. This means that the studies of leading specialists dedicated to social work are based on methodological approaches, aggregations of methods and technologies, generalized practical work experience applicable to most social sciences and humanities (Terziev, 2015b).

The concept of social work is inherently polysemantic. Presently, there are several approaches to its understanding amongst which more significant are the following (Terziev\&Dimitrova, 2014e): 
- The area of scientific knowledge about laws governing the utilization of internal and external resources of an individual, a family or a community being in difficult situations of inadequate social functioning;

- Specific type professional activity, manifestation of which is evident in rendering governmental and nongovernmental assistance to people in order to provide cultural, social and well circumstanced level of life, providing personal assistance to an individual, a family or group of persons;

- Rendering assistance within in the context off an of immediate interaction with individuals and families to resolve problems in their mental life, interpersonal relations, social and economic problems;

- Helping an individual placed in a difficult life situation, encouraging him to become socially selfsufficient, socially developed and socially active member of society;

- Type of activity of individuals and organizations providing assistance to various segments of population.

These definitions indicate that the social work is a particular type of activity of people aiming at providing help or assistance to various strata of society being in difficult life situation, also at creating conditions instrumental for the restoration or betterment of people's ability to social functioning (Terziev \& Dimitrova, 2014f).

The term "social work" in scientific and academic literature is most frequently defined as professional activity aimed at helping individuals, groups, communities to enhance or restore their capacity for social functioning and creating social conditions facilitating the implementation of this goal. Social work is also seen as a kind of social activity featuring specific levels of accomplishment conditioning its functions, forms and methods.

Also the following are included: individual social work, team social work, community organization, administrative social work, research, social policy, planning, immediate clinical practice, family and marital practices and other micro practices and also this, what is called the common practice of social work.

Methodology of social work is based on a system of well- substantiated knowledge gained through research and evaluation of practical activities. The theory of social work accounts for the complexity of interactions between individuals and their encirclement and recognizes people's ability both to be influenced and to alter the effect of multiple factors acting on them. Theoretical and methodological analysis of social work is based on the historical approach and identification of sources for the emergence of a phenomenon in the past (Terziev \& Dimitrova, 2014c).

Against the background of that what was stated above, scientific understanding of social work in Bulgaria begins with the manifestation of social role of the phenomenon of charity in public life, as well as with the attempts various philosophical, psychological, psychotherapeutic, sociological and medical approaches to be applied for the purposes of scientific justification of social protection of people, helping the needy.

Nowadays, theoretical justification of social work is developing in three main directions. First, the place of social work as a branch of knowledge amongst disciplines such as social philosophy, social history, political science, sociology, social psychology, cultural studies is determined. Second, an own theoretical constant of social work as a specific object of study is sought; and third, its interaction with other human and society science is shown. Taking into account that the social work is based on human factor understood as an individual, team and team members' relationships based on the awareness, the social nature of prime priority of its activity conditions the necessity of knowing the general and specific factors (Terziev \& Dimitrova, 2014d). As to general factors, attention should be given to general culture, special functional culture, factors of motivation, while the specific factors are associated with the manner of management decisions making, managerial intercourse and management responsibility.

Sticking to the logics of the study, the research is focused on a specific area of social work, such is the social adaptation of servicemen at the end of their career and making them ready for positions in the public and private sector of economics as a criterion for motivation and increasing the activity of the human factor in the field of security and defence (Human resource management concept of the MD, BA and structures directly subordinate to the Minister of Defence, S., 2006; Armed Forces Human Resources Management Doctrine (NP -1), an Ordinance of the Minister of Defence of the Republic of Bulgaria №OX- 179 dated 06.03.2013). Moreover, in contrast to previous studies, refracted through the prism of military department social policy, this study is aimed at offering the social and scientific knowledge a new perception of social adaptation of servicemen leaving the ranks of the Armed Forces and Bulgarian Army in accordance with the scientific understanding of the social work. 


\section{FEATURES OF SOCIAL WORK WITH SERVICEMEN AT THE END OF THEIR CAREER}

A baseline of current research served the specificity of social work with servicemen discharged from military service. The need for transparency and equal treatment of users of social services, paying respect to dignity of military brings out the role of social work with them (Terziev, 2015a). Hundreds of professionals moved from the army in the civil sector are able to make a substantial contribution to the reconstruction of Bulgarian society and to add value. Things are different in real life, where their experience and skills often give the impression that they are unnecessary. People who devoted their youth to the colours, as a rule are difficult to adapt to conditions of civilian life. Such a situation is not only immoral but also socially dangerous. People with special military-applied skills and knowledge actually form a new "risk group", especially when they fall come to the attention of criminal world. Very indicative on this issue are the various reports and analyses of the Ministry of Labour and Social Policy and the Ministry of Defence (Terziev, 2014).

The established practice shows that some of career service officers are experiencing serious difficulties finding a civil profession. Although highly qualified, many of them cannot find a job months in a row, lose the continuity of their working carrier or get deskilled. Working out the causes is based on an analysis of sociological and psychological studies materials enabling us to define the specifics of their self- and personal adaptation. Accordingly, the age groups of leaving the ranks of the AF and BA servicemen, social adaptation of who finds its manifestation in different ways.

In considering the main problems of socialization and adaptation of servicemen leaving the military service and their transition to civilian life environment resulting from their economic, age, psychological and social characteristics and their social status in modern conditions, the importance of social work targeting this category should be taken into account (Dimitrova \& Terziev, 2014a). This necessitates further development of already existing and newly developed forms of social work (Terziev et al. 2015b). Moreover, the servicemen social protection system has historically become a part of the national policy of a state. As such it should be further developed by actively interacting with all executive bodies and sectors of life in a country. In this context, attention should be given to appropriate best practices and their adaptation to the environment, accordingly.

In organizing the work on career development and social work with servicemen putting an end to their military career, regardless of reasons, as well as the work with their family members at national level, taking into account international experience is of significant importance. Undoubtedly, it is at least nonsense to believe that this experience can be transferred to the terms unalloyed, directly. In order to be used in the work of the social services, its bringing in conformity with Bulgarian specifics is a requirement. Almost hundred years' experience in the development of social work not only determines the modernization of the classical social thought paradigm, but also provides scientific foundation for new trends in the social reconstruction of society (Terziev, 2015a, b).

Theoretical growth of scientific knowledge in the field of social work in many countries of the world has been developing mainly in two directions. The first trend relates to promoting the importance of behavioural approach in the system of psychological explanation based on the theory of knowledge, on the domination of cognitive orientations. The second aspect is related to enhancing the interest in social work theoretical approaches (Terziev et al., 2015a).

In the long run, systematic concepts of social protection, social guarantees, and social services aimed at rendering assistance and support to people finding themselves in complicated life situations have been formed in the knowledge of social work. At that, orientation towards an overall approach to theory of social work, to the establishment of a legal foundation of social technologies is promoted.

Comparative analysis of international practice in the system of conversion training and social adaptation of servicemen who undergo transition to civilian life has provoked us to look for an answer to the following questions (Terziev, 2015a):

-What military personnel classes leaving the ranks of AF and BA are covered by this system?

- How the financing of military staff's preparation for the transition to civilian is arranged and who is irresponsible for the core measures in this process?

- Who is carrying out the process of social adaptation and what structures and organizations within and beyond the competences of the Department of Defence are involved?

-What is the technology of organization of the process of professional reorientation, conversion training and assistance in finding the servicemen discharged from military duty a job? 
- What is the time span for carrying out the work on conversion and social adaptation of military before and after their discharge from military service?

- How the availability of practical skills and competences acquired in the course of regular duty by those discharged from military service is reported?

- What is the ratio of discharged servicemen intending to undergo retraining in one civilian occupational specialty or another and those intending to turn to one business or another in such civilian and educational field at a later stage?

In pursuing answers to these key questions, we turn to the best practices in the field of conversion training and adaptation of the military personnel discharged from service and the members of their families. And it is quite understandably for us, as a member state of NATO, to focus on the practices and experience of the USA and many EU member states of this structures in this area. The practices of developed countries in Europe (the UK, France, Germany, etc.) confirm that servicemen discharged from military service prepare for civilian life prior to their releasing from the Armed Forces and the organization of this process is a responsibility of the ministries of Defence, and of course, subject to financial support from the state (Terziev, 2014).

Adoption of foreign experience in social protection of servicemen requires taking into account the complex of domestic and foreign policy factors influencing the processes taking place in a particular state. The existing models for social protection of servicemen worldwide can be divided into institutional, partially institutional and extra institutional. The institutional model is typical for the countries with developed legal systems, industrial or post-industrial economy, and democratic state system. There are clearly defined conditions of operation of the armed forces, a comprehensive civil control is carried out there, a functioning contract-based service system and an established legal framework for protection of the honour and dignity of the military. A well-developed system for material and social security of servicemen and members of their families allows the state to provide them with living standards higher than the national average. Institutional model defines the high prestige of military service in the public mind and its attractiveness for a significant part of the younger generation (Terziev \& Dimitrova, 2014g).

In countries where a social security institution is just beginning to form and the system of guarantees, compensations and benefits for servicemen sometimes has a casual and fragmentary character a partially institutional model is formed (Terziev, 2014). There, the peculiarity of the legal status of the armed forces and the military represents an opportunity to involve them in extrinsic functions implementation. In some cases, such decisions of the military and political leadership of a country could be taken in concurrence with the legislative authorities. Living standard of the military in partially institutional system is comparable to the average standard of living of the population. The prestige of the military service is substantially lower than in terms of the institutional model; military service in the public perception is ambiguous. There are certain difficulties with the provisioning of the armed forces. The choice of the military profession is often driven by the more favourable socio-economic conditions of life outside the army.

Extra institutional model is formed in countries where the military are an independent political force, being in power (or having unlimited influence on it). There, the military actually participate in political decisions and, if necessary, use firearms. They act under the wartime laws and conduct military dictatorship. Army members get considerably higher socio-economic benefits than civilians. The military cause fear and tension.

Social protection of servicemen in Bulgaria for the present is of partially institutional nature, and sometimes, in a number of signs is reduced to extra institutional model. The way ahead in its further development depends on the specific policies applied. More preferable is the way of strengthening the legal basis for the social protection of servicemen and provisioning plenty of the socio-economic and socio-cultural mechanisms, which means a move towards institutional model.

The analysis of the legal regulation concerning social protection of servicemen applied by the member countries Euro-Atlantic structures allows to highlight a number of specificities. Attention should be given to the following (Terziev, 2014):

- First, they regulate the status of the military both as a citizen, and as a special subject of public relations;

- Second, the underlying principle of legal regulation of the servicemen social protection system is the principle of compensation for specific burdens and hardships of the military service;

- Third, the special status of the military, the complex of their rights and privileges is constitutionally entrenched. 
- Fourth, the effectiveness of military legislation is conditioned by its systematization.

A distinctive feature of the legal regulation concerning social protection of foreign armies' servicemen is the establishment and effective functioning of special structures to the state administrative bodies within the immediate jurisdiction of which is the settlement of the said issues. European practice gives evidence that parliamentary scrutiny is the basis for a broad and developed system of civil control over the armed forces and the entire military. In Bulgaria, there are still many gaps in the implementation of parliamentary scrutiny, although there have been certain changes in this direction. However, a number of questions concerning armed forces activities that have significant social importance remain outside the regulating effect of the National Assembly. Speaking of this very day in Bulgaria, it is far from complete implementation of the possibilities inherent in the foundations of parliamentary system (Terziev \& Dimitrova, 2014b).

The existence of a network of public organizations at different levels is typical of the established in the Western countries social protection systems; there is a steady tendency to boost their role. Thus, the French experts consider it necessary to establish within the military organization special institutional frameworks for open discussion and early detection of problems at regiment (ship) level.

Social and psychological adaptation of soldiers passed in stock remains a problem of the day. They are changing the profession in advanced age, when others have made a career in civilian profession. As a result, on the background of tense situation, special difficulties are faced on the labour market, being exacerbated by the fact that in many countries (Terziev \& Dimitrova, 2014a).

Experts in the field of innovative military education in Bulgaria believe that indiscriminate borrowing of foreign practice is extremely dangerous. Meanwhile, others believe that the specifics of Bulgarian lifestyle, ideological heritage, and mentality of the population should not be exaggerated, since during the transition period they have not been so much significant factors of social development, as could be expected. Much greater impact has the state of economy, which crucially affects social processes, limits the choice of orientations and scales of social and political events, rising sometimes insurmountable barriers in the way to implementation of social policy (Dimitrova \& Terziev, 2014b).

Thus utilization of foreign practice and experience should be seen as a guideline to form a system and mechanisms for social protection of servicemen (Terziev et al., 2016). With all steadiness of the historical and national circumstances, they also undergo certain changes. Representative in this respect is the legal system, in the development of which the role of the state determinative. Such a role for the state gives the Bulgarian legal system that unique character that sets it apart from the legal systems of other European countries. This means that when taking certain legal concepts, models, and rules of the law, we must recognize the specific nature of the legal system that can radically transform foreign ideas and models. In this vein, we consider it necessary to trace Bulgarian specific practice for social adaptation servicemen, discharged from military service.

\section{PROCEDURES FOR SOCIAL ADAPTATION OF SERVICEMEN IN BULGARIA}

Solving the complex task of creating a system of social protection of servicemen, as a rule, affects all aspects of the life of society. Fundamentally new questions appear to economic, social, intellectual and other spheres. Solving a similar problem in Bulgaria is complicated by the significant reduction of the army, its reforming by applying professional principle of completion. Taking into account the international experience, it can be assumed that similar changes at home can cause new set of difficult and complex problems. In this case, attracting foreign partners and adopting joint training programs of soldiers moving into stock would be useful. Measures and actions in this area should be directed towards the implementation of programs and projects for motivation, training and retraining, job placement, starting own business and conversion of military property. Feasibility of the study of the labour market determines the need for professional orientation. This requires involvement of the military in training courses, providing learning opportunities at higher educational institutions awarding majors sought by employers, making them ready to start their own business, helping them with job placement. Accordingly, provided funding for training courses should be in proportion military budget - serviceman (70:30). Such an approach shall promote the aspiration for development of those servicemen who are subject to retirement or otherwise leaving the ranks of the Army and prepare them for self-actualization in civilian life. Training courses should be tailored to the requirements of the labour market (Terziev, 2015a, b).

In accordance with the above, the main types of social services can be classified as follows: professional orientation; assistance in professional retraining; job seeking assistance; legal assistance; social and psychological support; assistance in setting up, small business enterprises; information and consulting services; work with the families of servicemen who died while performing their military duty (Dimitrova \& Terziev, 2014c). 
Professional orientation and the choice of civil profession is the first step in preparing for the transition to stock. Assistance with professional retraining includes career choice and direction to professional retraining at educational units or professional training centres. As to the job seeking, it consists in rendering assistance on the part of specialists-professionals when choosing a future profession, and seeking suitable placement.

Legal assistance consists in information-consulting sessions with young officers on the mortgage system of housing of soldiers, providing legal advising to soldiers who have been wounded and more. Social and psychological support includes psychological diagnosis and psychological help using modern methods and also psychological support to servicemen found themselves in a difficult life situation. Assistance in the establishment of small business enterprises among servicemen discharged from military service is provided during information meetings on development of entrepreneurial activity among retired military personnel and their family members and others.

Information, consulting and methodological support include: disseminating information about the social protection services provided to servicemen, to those discharged from military service and their families (Labour Office, Social Assistance Directorates, etc.); creation of information-analytical data base on social adaptation issues; working out, publishing and distribution of guiding and reference literature; organizing information interaction with the media, with departments and organizations dealing with social protection of servicemen moving into reserve and their family members; working out, publishing and distribution of methodological instruments in relation to organization and carrying out military social work.

An important point is that the process of social adaptation initiates at the very military formation, before a serviceman is discharged from military service. To this effect, group and individual motivational talks are held, with the participation of experts from the National Employment Agency, and its territorial divisions, when possible. Motivation lectures within groups are organized by commanders and coordinators within the formation, being helped and assisted by consultants in adaptation from the District and Regional Military Departments to the Central Office of Military Districts (CMD). This means that before being released, a serviceman acquires an initial notion of the process of social adaptation and the possibilities for selfactualization in civil society.

Professional orientation of the military discharged from military service requires information on occupations and activities, employability requirements, training organizations and institutions, forms of study, documents issued upon completing the study, employment opportunities in the labour market. The choice of solution for civil profession/ specialty and referral to a related appropriate training is assisted by adaptation consultants to CMD structures. Within the scope of consultancy are included problems such: identification of knowledge, skills and experience gained during military service; formulation of social adaptation objectives and development of an individual plan; working out strategies for effective job searching and applying; getting acquainted with trends in the labour market, the sources of information on job vacancies; analysis of jobs adds and choice of jobs for application; application documents preparation: CV, recommendation/ profile letters and forms; interview with the employer; job offer assessment etc.

Consultants to CMD assist the registered military discharged from service in seeking job, providing information and directing them to the regional employment services, labour offices and other employers' organizations to be successful in the labour market. More particularly, they provide them information about: suitable jobs, including at another location in the country or in other countries; involvement in projects, programs and measures for employment and training carried out by other institutions and organizations; directing injured during or while performing their duties to programs and projects that support their social integration; including and increasing their employability and employment; preparation and participation in employment and information exchanges; meetings with employers and other forms of employment opportunities, organized in collaboration with the structures of the Employment Agency and other institutions and organizations.

Those willing to start their own business are assisted by the adaptation consultant, who advices them and refers them to training courses providing entrepreneurial, managerial and business skills; furnishes them with promotional and information materials to start their own business; inform about regional, national and European programs aimed at supporting entrepreneurs, crediting sources and other relevant information about starting their own business. Preparation for starting own business is directed at promoting activity and adaptability of the military discharged from active service, with the clear idea, desire and attitude to provide career development through self-employment and to start their own business.

It is noteworthy that Bulgaria has gained experience and methodological basis for the social and adaptation of the military honourably discharged from active service. Based on best practices- own and these of the member states of the Euro-Atlantic structures we considered appropriate to state the right direction to increasing the efficiency of social adaptation of servicemen released from military service. 


\section{MAIN DIRECTIONS FOR OPTIMIZATION OF SOCIAL WORK WITH THE MILITARY RELEASED FROM MILITARY SERVICE}

Much of the servicemen released from military service have a good education and sufficient social status. After moving in reserve, they are left alone with their problems and often become absolutely defenceless in the modern world of exchange relations.

It is necessary for former military to be involved in the entrepreneurship in order to create additional employment opportunities. Besides social and economic problems, the military that have moved into reserves and their family members also face difficulties in finding job, housing problems, family wealth impairment, little accessibility to health and recreational activities. All this is due to the fact that there is no an effective social policy to support such families. According to the representatives of all the departments, main cause, giving rise to this problem, is economic.

Studies allow to conclude that the establishment of a system for social adaptation of the military released from military service presently refers to the modern stage the most important directions in the social policy.

Nowadays, the need for further development of social work and various social technologies, giving significance to contemporary experience in the sphere of social services, becomes even more relevant.

An elaborated approach aimed at establishing a network of social service agencies, at creating a truly effective and necessary social protection system should be applied. Professionalism and morality should be regarded as personal qualities that every single social services specialist must be in possession of. Coordination between various administrative departments for social protection of the population, education, health, employment, etc. should be also enhanced- to meet the needs of the population in general.

The main obstacles to increasing the effectiveness of social work with servicemen passing to the reserve are:

- Unregulated legislation on the functions of social protection in the armed forces and the mechanisms for their implementation;

- Inadequacy and fragmentarily of the legal basis relating to issues of social and economic security of military personnel;

- Inadequate modern working conditions and retirement indemnity for servicemen;

- The absence of action programs for social adaptation of servicemen subject passing in stock;

- Delayed arrangement of housing problems;

- Imperfection of medical care system applicable to servicemen released from military service and to their family members;

-Weak legal basis of the social security system;

- Limited financial resources available at the disposal of government authorities at national and regional level, the deficit of funds in local government;

- Lack of coordination between the ministries and agencies in the field of social services;

- Shortage of staff who have professional training in social work;

- Low social status and inadequate wages of workers engaged in social services.

It is obvious that here, in Bulgaria, it is necessary to develop licensed activity services (delegated social service) in the area of social adaptation of the military released from military service, to ensure monitoring of the social service compliance with the state standards. It is important for normative and legal basis for the organization and functioning of the social welfare services to be developed, personnel support to social offices providing services to a particular category of citizens.

In recent years a number of measures have been adopted to improve the legal basis for social protection of servicemen released from military service and members of their families, given the changed social and economic conditions. Sociological studies conducted in Bulgaria and results analysis of annual monitoring of socio-economic and legal status of the military taken all round mark positive dynamics of the process of social adaptation of soldiers discharged from military service in recent years.

This process has a systematic and complex character and is performed by many social institutions and specialized agencies concerned with the organization of the social adaptation of the military released from 
military service and the members of their families. Arguably, the process of adaptation began acquiring institutional traits. However, inconsistencies in the implementation of programs for adaptation lead to serious regional disparity.

Against the background of the declining level of confidence in the bodies of legislative and executive power on the part of population the rating of the armed forces in other state and public institutions remains relatively high, though the military themselves do not value the military service prestige in modern Bulgarian society. And this is directly related to dissatisfaction with the level of concern of the state for their families, underestimation of the place and role they play in the protection of the state, etc. This controversial circumstance shows hidden reserves to improve social policy and social work in social adaptation of soldiers released from military service and members of their families.

Social protection of servicemen released from military service and their families is a wide range of legislative, organizational, professional, financial, psychological and other aspects relating to both everyday life and the inner realm of a man. The main tasks of the system for social protection of population in providing social support to the military, the honourably released part of their staff and their families can be specified as follow:

- Identifying the most topical issues of adaptation and social protection of servicemen released from military service;

- Support in providing medical, social, psychological, socio-economic, legal and other assistance;

- Interaction with the state and public organizations in search of servicemen released from military service due to illness or disability (people with fewer opportunities);

- Support to the families of servicemen in need of social assistance;

- Analysis of conditions and prospects for social security and services to participants in warfare, to the military released from military service and members of their families;

- Raising the living standards of the military and their families providing each of them the maximum possible under particular conditions social protection in accordance with the legislation of Bulgaria.

Based on the analysis performed we consider it appropriate to offer some recommendations to improve the system for social protection of servicemen released from military service.

Above all, it is necessary to establish the legal foundations of social protection of servicemen, also the social adaptation of the military released from military service and the members of their families. These are socioeconomic, political and personal rights and freedoms, which cannot be modified, cancelled or restricted by other normative and legal acts of lower level force. In other words, no legal regulation can contravene constitutional rights and freedoms of citizens.

A detailed and realistic military service contract is optative in order to provide for equal responsibility of servicemen to the state and, vice versa, of the state to servicemen. It is necessary to strengthen control over the legality of orders issued by commanders and superiors regarding the allocation/ distribution of material and household goods among employees, imposing disciplinary actions, as well as regarding compliance of their practical work with the principle of social justice in the formations they are being entrusted to. Most full effect here can be achieved by establishing Institute of delegated representation of the bodies of state power within the formations in the form of special agents (on the model of the army in Germany) who would come into the system from bodies engaged in social and legal activity.

It is desirable to improve the system for continuous qualification advancement of the military, including at civilian universities, making them ready for the conditions of "civilian" life, providing opportunities for members of their families to receive superior quality education, which in turn shall ensure their competitiveness in the labour market. It is necessary to set up sufficiently effective social-state structures to implement the support of the servicemen after their release from military service and transition into the stock.

We need to continue work on implementation of existing programs for social adaptation and social work with citizens released from military service and their families and to ensure privileges prescribed under the law. It is practicable to actively use the possibilities of social activity which involves such mechanisms as professional retraining of military personnel in the basics of entrepreneurship and small business, psychological consulting, legal services and other activities.

In this regard we consider beneficiary using new employment opportunities related to computers and new technologies. These types of activities, having high rehabilitation potential, contribute to self-assertion and can provide them with conditions for self-insurance. Complex development of the social protection of servicemen released from the ranks of the armed forces system calls for: 
- Further development and legislative endorsement of new basic social standards and norms for the quality of life for servicemen and those passing in stock;

- Defining mechanisms for their up-dating, development of medium and long-term social protection programs, providing social services and social benefits system reformation;

- Completing the legislative package with regulations governing the social protection issues that have not been reflected in national legislation so far;

- Adoption of urgent measures aimed at improving the retirement insurance;

- Development of a long-term program for economic security, adapted to modern economic relations, at that maintaining a focus on the participants in hostilities, war invalids, on family members of servicemen who have lost people providing for them;

- Supporting purchasing power of each family of military personnel within the conditions of continuing rise in prices and the going up cost of living through systematic readjustment/ indexation and compensation payments;

- Defining the mechanisms for recovery of the lost link between the amount of pension and monetary support of servicemen;

- Providing a radical solution to the housing problem in the Armed Forces.

Very recent creation of an effective, dynamic system of social adaptation of soldiers has succeeded to operatively and flexibly reorganize their structural divisions in order best to implement social policy of the state in life through a network of local state social service local government, public organizations.

In accordance with this requirement, a specialist of the given sphere need to:

- Have good professional training, knowledge in various areas of psychology, pedagogy, sociology, laws, economics and organization of production, computing, mathematical statistics and many other general professional and special disciplines;

- Have sufficient general and professional culture, to be deeply versed that presumes good knowledge in the humanities;

- Be informed about contemporary political, social and economic processes in society and widely aware of the standard of living and problems of different social groups;

- Foresee the consequences of his actions and firmly pursue his position in life;

- Be in possession of certain social adaptability in relation to diversity of population needing advices of the social activity specialist;

- Skilfully communicate and predispose the "difficult" growing ups, orphans, deserted women, people with limited opportunities, elderly, people in vindication etc.;

- Possess professional skills and experience, to be able to provoke sympathy and trust, to keep professional confidentiality, to show sense of delicacy in all matters concerning intimate aspects of human life, to have emotional stability, to be ready for mental loads, to avoid neurotic deviations in their own judgments and actions despite possible failures (not pertinent reactions, refusals, etc.);

- Be able to conscientiously perform own duty, remaining calm, benevolent and attentive to the ward;

- Be able to take appropriate decision in extreme situations, to formulate his thoughts, literate and understandable to set them forth.

\section{CONCLUSION}

In summary of above fragments of the social adaptation of the military released from military service and passing in stock we believe that it should be regarded as part of a comprehensive system for social work and protection of intellectual capital in Bulgaria that is in possession of value adding knowledge and skills. As soldiers are part of this capital, of the quality of social work carried out for adaptation to civilian life, possibilities for their smooth adaptation to civilian life and effective use of their skills and competencies carrying value and competitive advantage are determined. We make no claim to comprehensiveness of problems considered in current study but we purport to contribute to scientific knowledge in the field of social adaptation of servicemen leaving the ranks of the Armed Forces and the Bulgarian Army providing the view on this such a topical issue in the conditions of strengthening budget deficit and dynamic changes in security environment. And the effectiveness of the implementation of a cost- based system of social adaptation and 
protection is directly related to compliance with the principles of legality, integrity, impartiality, accountability, professionalism, competence, positivity, accessibility, humanity, transparency, equal treatment of social services users and the dignity of the military and civilian personnel along with all other members of the society.

\section{REFERENCE LIST}

Armed Forces Human Resources Management Doctrine (NP -1), an Ordinance of the Minister of Defence of the Republic of Bulgaria №OX-179 dated 06.03.2013.

Dimitrova, S., Terziev, V. (2014a). Social and educational conditions for adaptation of former military personnel and their family member, International Scientific Technical Conference "Technics. Technologies. Education. Safety", 29-30 May 2014. Veliko Tarnovo, Bulgaria, pp. 15-17.

Dimitrova, S., Terziev, V. (2014b). The social adaptation of the military, discharged from military servicenecessary or by request, 11th International Academic Conference, 24-27 June 2014, Reykjavik, pp. 58-80.

Dimitrova, S., Terziev, V. (2014c). Theoretical study on a pilot implementation of a working model of the process of social adaptation former military personnel and their families in Bulgaria, KSI Transactions on Knowledge Society, A publication of Knowledge Society Vol. VII, N 1, Ensuring Sustainable Development in the Period After the Financial Crisis, March, 2014, pp. 53-57.

Ministry of Defence of the Republic Bulgaria, 2006. Concept of human resource management in the Ministry of Defence, armed forces and structures directly subordinate to the Minister of Defence, Sofia, Bulgaria.

Terziev, V. (2014). Vazmozhnosti za povishavane na efektivnostta na sotsialnata adaptatsiya na voennosluzheshti, osvobodeni ot voenna sluzhba, Primaks Ruse, Bulgaria.

Terziev, V. (2015a). Opportunities for improving the efficiency of the social adaptation of servicemen discharged from military service in Bulgaria. Novosibirsk: Publisher CRNS.

Terziev, V. (2015b). Predizvikatelstva pred sotsialnoto pragramirane v konteksta na nasarchavane na sotsialnata aktivnost i regulirane na sotsialnoto razvitie chrez aktivni politiki, Primaks Ruse, Bulgaria.

Terziev, V., Bogdanov, P., Madanski, V., Stefanov, S. (2016). Approaches to social adaptation of servicemen discharged of military service, VII international scientific and applicative conference Knowledge Without Borders, 8-10 April 2016, Bulgaria. Knowledge International Journal Scientific papers Vol. 12.2, pp. 85-97.

Terziev, V., Dimitrova, S. (2014a). A new approach to social adaptation of decommissioned servicemen and their families, The 20th International Conference The Knowledge-Based Organization, "Nicolae Balescu" Land Forces Academy, Publishing House Sibiu, Economic, Social and Administrative Approaches to the Knowledge-Based Organization, 12-14 June 2014, Conference Proceedings 2, pp. 359-364.

Terziev, V., Dimitrova, S. (2014b). A new view on social adaptation of the military, discharged from military service in Bulgaria, "Improving Life Quality and Enhancing Employment Possibilities", SOCIN International Interdisciplinary Conference on Social Innovations, October 23-24, 2014, Mykolas Romeris University, Vilnius, Lithuania, pp. 129-133.

Terziev, V., Dimitrova, S. (2014c). An attempt at theoretical study of the implementation of a working model of social adaptation of servicemen released from the army, $12^{\text {th }}$ International Conference Information Technologies and Management 2014, Information Systems Management Institute, Riga, Latvia, pp. 194-195.

Terziev, V., Dimitrova, S. (2014d). New model of social policy in Bulgaria on adaptation of the military, discharged from the military services, $14^{\text {th }}$ International Academic Conference, Malta, 28 October 2014, IISES, pp. 425-443.

Terziev, V., Dimitrova, S. (2014e). Social adaptation as a social process in the adaptation of military personnel, $13^{\text {th }}$ EBES Conference, Istanbul, June 5-7, 2014, Istanbul, Turkey, pp. 1956-1966. 
Terziev, V., Dimitrova, S. (2014f). Social adaptation as a social process in the adaptation of military personnel, Climate Change, Economic Development, Environment and People Conference (CCEDEP), 7-9 October 2014, Plovdiv, Bulgaria. Proceedings Volume 1 (2015), pp. 108-136.

Terziev, V., Dimitrova, S. (2014g). Structural levels and phases in the process of social adaptation of laid-off Bulgarian army servicemen and their family members, $14^{\text {th }}$ EBES Conference- Barcelona, October 23-25, 2014, pp. 3103-3119.

Terziev, V., Dimitrova, S., Arabska, E. (2015a). Aspects of the interaction of structures and authorities for social adaptation of militaries exempted from military service and their families. Defence Technology Forum 2015 Shumen, International Scientific Conference 2015, Exhibition of Modern Defence Products 2015, October 23-24, 2015, "Vasil Levski" National Military University, Artillery, Air Defence and CIS Faculty, Shumen, Bulgaria, Collection of papers, pp. 193-199.

Terziev, V., Dimitrova, S., Arabska, E. (2015b). Social needs of militaries exempted from military service and members of their families and their satisfaction. Defence Technology Forum 2015 Shumen, International Scientific Conference 2015, Exhibition of Modern Defence Products 2015, October 23-24, 2015, Vasil Levski National Military University, Artillery, Air Defence and CIS Faculty, Shumen, Bulgaria, Collection of papers, pp. 200-204. 